\title{
Insect Pollinator Diversity in Major Traditional Leafy Vegetables Kale (Brassica oleracea var. acephala) and Knol Khol (Brassica oleracea var. gongylodes) of Kashmir Himalayas
}

\author{
Deelak Amin*, Muneer Ahmad, Shifa and Shahida Ibrahim
}

Division of Entomology, Sher-e-Kashmir University of Agricultural Sciences and Technology, Shalimar, Srinagar, Kashmir, J\&K-190025, India

*Corresponding author

\begin{tabular}{|c|c|}
\hline & A B S T R A C T \\
\hline $\begin{array}{l}\text { Ke y w o r d s } \\
\text { Pollinator, Diversity, } \\
\text { Traditional, Vegetable, } \\
\text { Himalayas }\end{array}$ & \multirow{3}{*}{$\begin{array}{l}\text { The present investigation was conducted at vegetable seed production unit, Division of } \\
\text { vegetable Science, Shuhama campus, SKUAST-Kashmir during } 2014-15 \text { on leafy } \\
\text { vegetables viz., knol kohl and kale crops. The pollinator fauna of both the vegetables were } \\
\text { collected and studied for their foraging ecology and behaviour during the study period. } \\
\text { There are various threats to pollinator diversity in modern agriculture. Our focus was to } \\
\text { record the insect diversity under present scenario. The collected pollinators/visitors of } \\
\text { knoll khol and kale were identified and total of } 15 \text { insect pollinators/visitors belonging to } \\
\text { orders and families of class insect were recorded from knoll khol bloom while as } 17 \text { insect } \\
\text { pollinators/visitors belonging to orders and } 10 \text { families were recorded from kale bloom. } \\
\text { Among all pollinator, Hymenopterans were most predominant contributing } 91.64 \% \text { of total } \\
\text { pollinators on knoll khol and } 90.04 \% \text { of total pollinators on kale. }\end{array}$} \\
\hline Article Info & \\
\hline $\begin{array}{l}\text { Accepted: } \\
\text { 26 February } 2018 \\
\text { Available Online: } \\
10 \text { March } 2018\end{array}$ & \\
\hline
\end{tabular}

\section{Introduction}

Kale (Brassica oleracea var. acephala) and Knol khol (Brassica oleracea var, gongylodes), are widely used in Kashmir as vegetables. In Kashmir, these are popular vegetables both among rich and poor and grown in almost all kitchen gardens and also as a commercial crop around cities and towns. Kale grown in Kashmir is popularly known as ' $H A K$ ' and Knol khol as 'MONJE HAK'. In Kashmir, Kale and Knol Khol are grown round the year but they shine most as cold winter crops and are at their most flavourful and tender condition during winter months. The area under Kale crop in Kashmir valley is nearly 3600 ha with an annual production of $1,06,780$ tonnes while as area under Knol Khol crop in Kashmir valley is 4,500 ha with an annual production of $1,28,850$ tonnes (Anonymous, 2012). These traditional vegetables are under cultivation since ancient times. In India, kale is not being grown as a vegetable crop for commercial use, however it is commercially grown in Kashmir and to a limited extent in Jammu, Assam, and Himachal Pradesh (Choudhary, 1977). Also knol khol is popularly grown in Kashmir, West Bengal, Maharashtra, Assam, Uttar Pradesh, Punjab and some parts of south India, but it is not cultivated commercially. Knol khol is an herbaceous plant, edible portion of 
which is the swollen stem just above the ground. The small leaves grow out of this stem arranged in compressed spiral on this bulbous part (Nath et al., 1994). This knob is harvested for human consumption as raw or cooked vegetables, though in some parts, young leaves are also used. They are highly nutritious vegetables like other members of Brassica family, rich in vitamins particularly vitamin $C$, pro vitamin $A$ and minerals such as calcium phosphorus, potassium, magnesium, etc. and are excellent source of fiber. They contain health promoting phytochemicals such as isothiocyanates, sulforaphane, and indole-3carbinol that are supposed to protect against prostate and colon cancers and have high amount of total nitrogen, raw proteins, fats, carbohydrates and amino acids. Both crops are rich in leucine, isoleucine, arginine, phenylalanine and lysine while equally good in threonine, tryptophan and histidine. Daily consumption of leafy vegetables lowers the risk of cancer and heart diseases, prevents tiredness, helps keeping well condition and prevents senescence (Kolton and Baran, 2008).

These crops are grown both during kharif and rabi season but for seed production only rabi crop is taken. Crop matures before the arrival of cold, flowering occurs in the month of March and in June-July seeds are harvested. Length of photoperiod has no significant effect on induction of flowering, but most brassicas require vernalization for flowering and seed setting. Vernalization requires exposure to a temperature of 39 to $50^{\circ} \mathrm{F}$ (4 to $10^{\circ} \mathrm{C}$ ) for at least four to six weeks (McCormack, 2005). Brassica flowers are hermaphrodite and are borne in racemes. These flowers open during the early hours of daylight and few hours later, the anthers dehisce exposing their pollen but the stigma is receptive for about five days prior to anthesis and up to four days after anthesis and during this time period cross-pollination is obligatory
(McCormack, 2005). These crops are highly cross-pollinated (Kale $83 \%$ and Knol khol $91 \%$ ) and mode of pollination is entomophily. The most effective pollinators are bees and flies. These crops have limited blooming period and due to the variable environmental conditions the potential of bees are not harnessed to their maximum due to which there is reduction in seed yield of the crop. Attempts are to be made to increase bee visits to the crop in the limited favourable period which will increase the seed yield.

\section{Materials and Methods}

To achieve the set objectives the following experiments was carried out at vegetable seed production unit, shuhama campus, SKUAST$\mathrm{K}$ and the study were made on crops (Kale and Knol khol), raised during Rabi season of 2013-2014. The experimental site was situated at a distance of about $8 \mathrm{Km}$ from Shalimar campus, SKUAST-K. It is located at latitude of $34.23^{\circ}$ North and longitude of $74.78^{\circ}$ East and $1616 \mathrm{~m}(5302 \mathrm{ft})$ above mean sea level. The study was made on the kale and knol khol fields raised during 2013-14. The experimental plot was kept free from any spray during flowering period. Five spots of 1 $\mathrm{m}^{2}$ area were selected randomly for observation. Observations were made for different groups of pollinators visiting these crops during peak flowering at 1000 to 1100 hr., 1200 to $1300 \mathrm{hr}$. and 1400 to $1500 \mathrm{hr}$. for five minutes in each of the selected spots. Also unidentified pollinators were collected by using standard insect collecting hand net and were pinned, labelled and later identified. The collected data was later subjected to statistical analysis to infer the pollinator fauna as well as the dominance/relative abundance of particular group. Relative abundance of dominant species of pollinator was worked out by using the following formula after pooling all the data given by Nath and Virakthamath, 2010. 

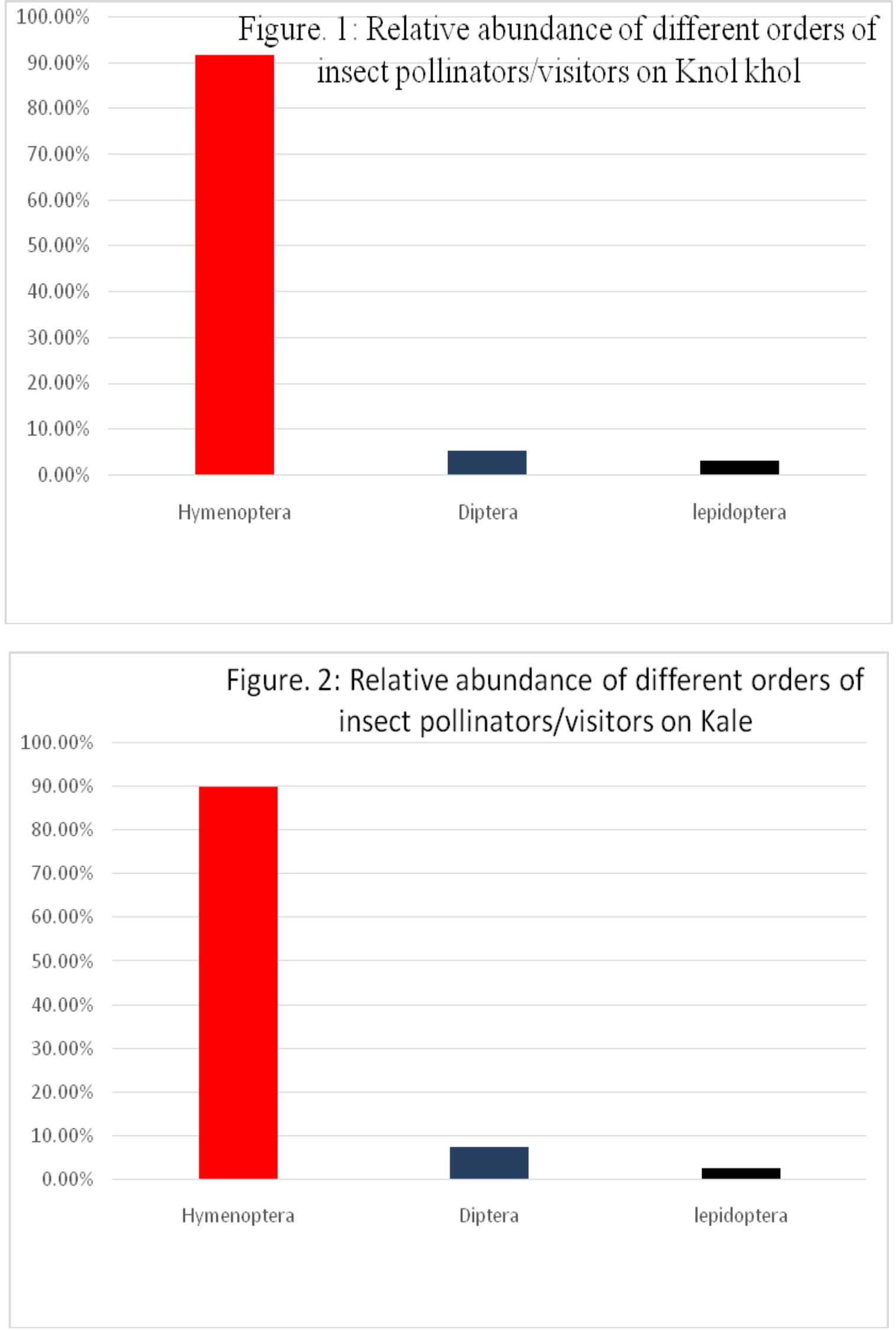
Table.1 Insect pollinators/visitors identified on Knol khol

\begin{tabular}{|c|c|c|c|c|}
\hline S no. & Pollinator/visitor & Systematic position & $\begin{array}{c}\text { Relative } \\
\text { abundance of } \\
\text { insect orders (\%) }\end{array}$ & $\begin{array}{c}\text { Relative } \\
\text { abundance of } \\
\text { pollinators (\%) }\end{array}$ \\
\hline $\begin{array}{l}1 . \\
2 . \\
3 . \\
4 . \\
5 . \\
6 . \\
7 . \\
8 . \\
9 . \\
10 . \\
11 . \\
12 . \\
13 . \\
14 . \\
15 .\end{array}$ & $\begin{array}{l}\text { Lasioglossum marginatum } \\
\text { Apis cerana } \\
\text { Apis mellifera } \\
\text { Andrena spp. } \\
\text { Xylocopa valga } \\
\text { Eristalodesparia } \\
\text { Eristalis tenax } \\
\text { Eoseristaliscerealis } \\
\text { Sphaerophoriabengalensis } \\
\text { Metasyrphusbacculatus } \\
\text { Plecia spp. } \\
\text { Scathophaga spp. } \\
\text { Callophora sp. } \\
\text { Vanessa cordui } \\
\text { Pierisbrassicae } \\
\text { Danauschrysiphus }\end{array}$ & $\begin{array}{l}\text { Halictidae: Hymenoptera } \\
\text { Apidae: Hymenoptera } \\
\text { Apidae: Hymenoptera } \\
\text { Andrenidae: Hymenoptera } \\
\text { Apidae: Hymenoptera } \\
\text { Syrphidae: Diptera } \\
\text { Syrphidae: Diptera } \\
\text { Syrphidae: Diptera } \\
\text { Syrphidae: Diptera } \\
\text { Syrphidae: Diptera } \\
\text { Bibionidae: Diptera } \\
\text { Scathophagidae: Diptera } \\
\text { Callophoridae: Diptera } \\
\text { Nymphalidae: Lepidoptera } \\
\text { Pieridae: Lepidoptera } \\
\text { Danidae: Lepidoptera }\end{array}$ & $\underbrace{-} 3.12$ & $\begin{array}{r}38.2 \\
27.09 \\
20.13\end{array}$ \\
\hline
\end{tabular}

Table.2 Insect pollinators/visitors identified on Kale

\begin{tabular}{|c|c|c|c|c|}
\hline S no. & Pollinator/visitor & Systematic position & $\begin{array}{l}\text { Relative abundance } \\
\text { of insect orders (\%) }\end{array}$ & $\begin{array}{c}\text { Relative } \\
\text { abundance of } \\
\text { pollinators }(\%)\end{array}$ \\
\hline 1. & Lasioglossum marginatum & Halictidae: Hymenoptera & & 38.31 \\
\hline 2. & Apis cerana & Apidae: Hymenoptera & & 26.67 \\
\hline 3. & Apis mellifera & Apidae: Hymenoptera & & 17 \\
\hline 4. & Andrena spp. & Andrenidae: Hymenoptera & 90.04 & \\
\hline 5. & Xylocopa valga & Apidae: Hymenoptera & & \\
\hline 6. & Bombus tunicatus & Apidae: Hymenoptera & & \\
\hline 7. & Eristalodesparia & Syrphidae: Diptera & & \\
\hline 8. & Eristalis tenax & Syrphidae: Diptera & & \\
\hline 9. & Eoseristaliscerealis & Syrphidae: Diptera & & \\
\hline 10. & Sphaerophoriabengalensis & Syrphidae: Diptera & & \\
\hline 11. & Metasyrphusbacculatus & Syrphidae: Diptera & 7.31 & 18.02 \\
\hline 12. & Plecia spp. & Bibionidae: Diptera & & \\
\hline 13. & Scathophaga spp. & Scathophagidae: Diptera & & \\
\hline 14. & Callophorasp. & Callophoridae: Diptera & & \\
\hline 15. & Bombyliinisp. & Bombyliidae: Diptera & & \\
\hline 16. & Vanessa cordui & Nymphalidae: Lepidoptera & & $\longrightarrow$ \\
\hline 17. & Pierisbrassicae & Pieridae: Lepidoptera & 2.67 & \\
\hline
\end{tabular}


Relative abundance of pollinator $=($ Number of individuals of pollinator visiting flowers / Total no. of pollinators visited) $\mathrm{x} 100$

The weather data like temperature, humidity, wind speed and sunshine were also recorded to correlate with the presence of pollinators.

\section{Results and Discussion}

Pollinators of KNOL Khol:- Insect pollinators collected from the bloom of knol khol during the year 2014 are listed in Table 1. A total of 15 insect pollinators/visitors belonging to 3 orders and 10 families of class insecta were recorded on knol khol bloom from Faculty of veterinary science Shuhama campus, SKUAST-K. Out of these, 5 pollinators belonged to Hymenoptera, 8 to Diptera and 3 to Lepidoptera. It was observed that among 5 hymenopteran pollinators, 4 were identified upto species viz., Lasioglossum marginatum, Xylocopa valga, Apis cerana, Apis mellifera and one upto genera viz., Andrena spp. represented by three families Halictidae, Andrenidae and Apidae. Out of 8 Dipteran insects, 5 pollinators were identified upto species viz., Eristalodesparia, Eristalis tenax, Eoseristalis tenax, Sphaerophoria bengalensis, Metasyrphus bacculatus and 3 upto genera viz., Plecia spp., Scathophaga spp. And Callophora spp. Which Belonged to 4 families, Syrphidae, Bibionidae, Scathophagidae and Callophoridae. In case of Lepidoptera only 3 species were identified viz., Pieris brassicae, Danausc hrysippus and Vanessa cordui belonging to 3 families, Nymphalidae, Pieridae and Danidae.

\section{Relative abundance of insect pollinators/visitors on knol khol bloom}

The total number of insect pollinators/visitors species recorded on kale bloom was 15 , out of which 5 belonged to Hymenoptera and constituted $91.64 \%$ of total pollinators, 8 to
Diptera contributing $5.24 \%$ of total pollinators and 3to Lepidoptera which contributed only $3.12 \%$ to total pollinators. Among Hymenopterans Lasioglossum marginatum was the most dominant pollinator constituting $38.20 \%$ followed by Apis cerana which constituted 27.09\%, and Apis mellifera constituting $20.13 \%$ while rest of the pollinators collectively constituted only $14.58 \%$ and were categorized as other pollinators (Table 1, Fig. 1). Investigations carried out on the pollinator fauna visiting Knol khol bloom revealed that three groups of pollinators belonging to different orders of class insecta visited the Knol khol during flowering period. Among different insect orders observed, Hymenopterans (5 species) were the most abundant group (Fig. 1) constituting $91.64 \%$, followed by Dipterans ( 8 species) $5.24 \%$ and Lepidopterans (3 species) $3.12 \%$. These findings are in close agreement with Sihag (1986) who reported nine species of Hymenopterans, six species of Lepidopterans and three species of Dipterans as predominant visitors of radish flower, out of which Hymenopterans were most abundant. Similar results were also reported by Priti et al., (2001) on radish flowers. Investigations carried out on the pollinator fauna visiting Kale bloom revealed that three groups of pollinators belonging to different orders of class insecta visited the Kale during flowering period (Table 2). Among different insect orders observed, Hymenopterans (6 species) were the most abundant group (Fig. 2) constituting $90.04 \%$, followed by Dipterans (9 species) $7.31 \%$ and Lepidopterans (2 species) $2.67 \%$. These findings are in close agreement with Sihag (1986) who reported nine species of Hymenopterans, six species of Lepidopterans and three species of Dipterans as predominant visitors of radish flower, out of which Hymenopterans were most abundant. Similar results were also reported by Priti et al., (2001) on radish flowers. 


\section{References}

Abrol, D. P. 1996. Sunflower pollination, abundance and diversity of pollinating insects and their effect on seed yield. Indian Bee Journal, 58: 60-63.

Ahmad, M. and Aslam, M. 2002. Pollinators visiting carrot (Daucus carota) seed crop. Journal of research (science), 13(1): 3135 .

Ambrose, J. T., Schultheis, J.R., Bambara, S.B. and Mangum, W. 1995 An evaluation of selected commercial bee attractants in the pollination of cucumbers and watermelons. American Bee Journal, 135(4): 267-272.

Anita, M., Sivaram, V and Jayaramappa, K. V. 2012. Influence of bee attractants on pollination and yield parameters in Guava (Psidium guajava L.) The International Journal of Plant Reproductive Biology 4(1): 41-46, 2012.

Anonymous, 2012, Status of vegetable crops. Department of Agriculture, Jammu and Kashmir.

Bhat, S. S. and Sudarshan, M. R. 1999. Studies on the efficacy of "Bee-Q" in augmenting pollination, fruit and seed set in cardamom (Elettaria cardamomum). A preliminary report. Indian Bee Journal, 61(1-4): 49-54.

Bhatia, R., Koul, B. L. and Sharma, A. K. 1999. Pollinator fauna of carrot (Daucus carota) and radish (Raphanus sativus) in foot hills of Himachal Pradesh and its role in fruit set. Journal of Hill Research, 12 (2): 154156.

Bhosle, B.B., Shetgar, S.S., Bilapate, G.G. and Londhe, G.M. 1992. Effects of attractant sprays for pollinators on sunflower yield. Journal of Maharashtra Agricultural Universities, 17(1): 135-145.

Bisht, D. S., Naim, M. and Mehrotra, K. N. 1983. Studies on role of honey bees in rape seed production. Proceedings of the Second International Conference Apiculture Trophical Climates, New Delhi. Feb 29- March 4, 491-496.
Butts, K.M. 1991. Bee attractants: improving strawberry quality. Citrus-and-VegetableMagazine, 55: 3, 12, 16-17 (CAB Abst. 4 of 28).

Chandrashekhar, G.S, Sattigi, H.N. 2005. Influence of bee attractants on bee pollination on seed quality and yield in radish. Karnataka Journal of Agricultural Sciences, 22(4): 777-780, 2009.

Chandrashekhar, G.S. and Sattigi, H.N. 2009. Influence of attractants on bee visitation to radish. Karnataka Journal of Agricultural Sciences, 22(4): 909-911

Chaudhary, B. 1977. Leafy vegetables. In: vegetables. National book trust of India, New Delhi, Pp. 193-194.

Chaudhary, O. P. 2001. Abundance of wild pollinators on rape seed and mustard. Insect Environment, 7(13): 141-142.

Currie, R.W., Winston, M.L., Slessor, K.N. and Mayer, D.F. 1992. Effect of synthetic Queen mandibular pheromone sprays on pollination of fruit crops by Honey bees (Hymenoptera: Apidae). Journal of Economic Entomology, 85(4): 1293-1299.

Ellis, A. and Delaplane, K.S. 2009. An evaluation of fruit- Boost as an aid for honey bee pollination under conditions of competing bloom. Journal of Apicultural research and Bee world. 48(1): 15-18.

Elmstrom, DN.GW and McCuistion, FT. Jr. 1992. Periodicity of watermelon fruit set and effect of bee attractants on yield. XXXVIII Annual meeting of the Inter American Society for Tropical Horticulture, Proceedings-of-the-Inter American-Society-for-Tropical-Horticulture. 1992. 36: 81-87; (CAB Abst. 9 of 28).

Evans, A., Schaffer, M. Wratten, S. D., Frampton, C., France, C. and Popay, S. J. 1995. The Influence of a fly attractant on hybrid carrot pollination. Proceedings of the Forty-eighth New Zealand Plant Protection Conference, pp. 294-296.

Finta, K. 2005. Controlled bee pollination of apple, and methods for improving the efficiency of honeybees in apple pollination. Acta Agronomica, 47(2): 119134. 
Ganapathi, K. and Viraktamath, S. 2007. Effect of bee attractants on bee visits and yield parameters of MECH-184 BT hybrid. Advances in pollen spore research, Solomon Raju, A.J. (editor) New Delhi, vol. XXIV pp 179-190.

Gellert, M., Rozsa, Z., Kovacs, Z., Szendrei, K., Hussai, R. A., Reisch, G., Reisch, J. 1985. Honey-bee attractants in the fruits of Evodia hupehensis Dode. HerbaHungarica, 24(1); 53-65.

Goyal, N. P., Monjit Singh and Kandoria, J. L. 1989. Role of insect pollination in seed production of carrot (Daucus carota Linn.). Indian Bee Journal, 51(3): 89-93.

Gupta, M. 1999. Relative abundance and diversity of different pollinating insects on sunflower hybrids (Helianthus annuus). Annals of Biological research Ludhiana, 15(1): 113-115.

Guruprasad, G. S. 2001. Maximization of productivity of Niger through enhancement of pollination. M.Sc (Agri) Thesis, University of Agricultural Sciences Dharwad (India).

Henning, J. A., Ying, S. and Mentague, M. A. 1992. Honey bee behavioural responses to primary alfalfa floral volatiles. Journal of Economic Entomology, 85(1): 233-239.

Higo, H.A., Winston, M.L. and Slenssor, K.N. 1995. Mechanism by which Honey Bee (Hymenoptera: Apidae) Queen Pheromone sprays enhance pollination. Annals of the Entomological Society of America, 88(3): 399-373.
Hill, D. 1975. Agricultural insect pests of tropics and their control. Cambridge University Press, Cambridge. pp.516

Jayaramappa, K .V. and Sivaram, V. 2013. Some aspects of bee attractants on Pumpkin Journal of Chemical, Biological and Physical Sciences, 3(3), 1801-1807.

Jayaramappa, K.V, Mahesh Pattabhiramaiah and Bhargava, H.R. 2011. Influence of Bee-attractants on Yield Parameters of Ridge Gourd (Luffa acutangula) (Cucurbitaceae). World Applied Sciences Journal 15 (4): 457-462, 2011

Kakar, K. L. 1980. Prospects of bees as pollinating agents of cauliflower. Paper presented at the Second international conference on apiculture in tropical climates, New Delhi, Feb. - Mar., p. 3.

McCormack, J.H. 2005. Brassica seed production cooperative state research extensive and extensive service; Http:// creativecommons.org traces/bync-nd/2.0/.

Nath, S. and Virathamath, S. 2010. Pollinator fauna of sunflower and their relative abundance. Karnataka journal of agriculture science. 23(3): 517-518

Priti and Sihag, R. C. 1998. Diversity visitation, frequency, foraging behaviour and pollinating efficiency of different insect pollinators visiting carrot, (Daucus carota) blossoms. Indian Bee Journal, 60(1): 1-8.

Sihag, R. C. 1986. Insect pollination increases seed production in Cruciferous and Umbelliferous crops. Journal of Apicultural Research, 25(2): 121-126

\section{How to cite this article:}

Deelak Amin, Muneer Ahmad, Shifa and Shahida Ibrahim. 2018. Insect Pollinator Diversity in Major Traditional Leafy Vegetables Kale (Brassica oleracea var. acephala) and Knol Khol (Brassica oleracea var. gongylodes) of Kashmir Himalayas. Int.J.Curr.Microbiol.App.Sci. 7(03): 3082-3089. doi: https://doi.org/10.20546/ijcmas.2018.703.358 